\title{
PENGARUH PEMBERIAN ESTER STANOL TERHADAP KADAR KOLESTEROL TOTAL PADA WANITA PENDERITA HIPERKOLESTEROLEMIA
}

\author{
Galuh Pradnya D, Tatik Mulyati* \\ Program Studi Ilmu Gizi Fakultas Kedokteran Universitas Diponegoro \\ Jl.Dr.Sutomo No.18, Semarang, Telp (024) 8453708, Email : gizifk@undip.ac.id
}

\begin{abstract}
Background : Hypercholesterolemia have been shown to be one of the factors associated with cardiovascular disease. Stanol ester is produced via esterification of plant stanols and have structurally related to cholesterol, but differ from cholesterol in the structure of the side chain. Stanol ester may displace cholesterol from mixed micelles.

Methods : This research was true experimental study with control group pre-test post-test design. Subject were women with serum total cholesterol level $\geq 200 \mathrm{mg} / \mathrm{dl}$, classified into 2 groups, treatment group consuming $3.4 \mathrm{~g}$ stanol ester/day and control group consuming placebo. Stanol ester was consumed during 14 days. Blood was collected after an overnight fast. Serum total cholesterol level was measured with CHOD-PAP method. Shapiro Wilk was used to analyze normality of the data. The statistical analyzes include dependent t-test, Wilcoxon, independent t-test and Mann Whitney.

Result : Consumption low-fat milk addition stanol ester $3.4 \mathrm{~g} /$ day in treatment group can reduce total cholesterol level $20.64 \mathrm{mg} / \mathrm{dl}$ or $8.71 \%$. Consumption low-fat milk no added stanol ester in control group was reduce total cholesterol level $16.92 \mathrm{mg} / \mathrm{dl}$ or $7.06 \%$. There was no statistic difference between treatment group and control group $(p=0.448)$.

Conclusion : Low-fat milk enriched with $3.4 \mathrm{~g}$ of stanol ester was no difference of total cholesterol level between control and treatment groups.
\end{abstract}

Keyword : Stanol Ester; serum total cholesterol; hypercholesterolemia

\begin{abstract}
ABSTRAK
Latar Belakang : Hiperkolesterolemia merupakan faktor risiko terjadinya penyakit jantung dan pembuluh darah. Ester stanol merupakan bentuk esterifikasi dari stanol, memiliki struktur kimia menyerupai kolesterol dan dapat menurunkan kadar kolesterol dengan cara berkompetisi dengan kolesterol untuk membentuk misel pada saat proses absorpsi.

Metode : Jenis penelitian adalah true experimental dengan rancangan pre-post test control design. Subyek adalah 28 wanita dengan kadar kolesterol total $\geq 200 \mathrm{mg} / \mathrm{dl}$, kelompok perlakuan mendapat $3.4 \mathrm{~g} / \mathrm{hari}$ ester stanol dan kelompok kontrol mendapat plasebo. Intervensi dilakukan selama 14 hari. Metode CHOD-PAP digunakan untuk menganalisis kadar kolesterol total, darah diambil setelah subyek berpuasa selama 10 jam. Uji normalitas menggunakan Shapiro Wilk. Analisis statistik menggunakan uji dependent t-test, Wilcoxon, independent t-test dan Mann Whitney.

Hasil : Pemberian susu rendah lemak ditambah ester stanol dengan dosis $3.4 \mathrm{~g}$ menurunkan kadar kolesterol total sebanyak $20.64 \mathrm{mg} /$ dl atau 8.71\%, sedangkan kelompok kontrol dengan pemberian susu rendah lemak menurunkan kadar kolesterol total sebanyak $16.92 \mathrm{mg} /$ dl atau $7.06 \%$. Secara statistik tidak terdapat perbedaan kadar kolesterol total ( $p=0.448$ ) antara kelompok kontrol dan kelompok perlakuan.

Kesimpulan : Pemberian ester stanol $3.4 \mathrm{~g}$ per hari selama 14 hari dibandingkan dengan kelompok kontrol (susu rendah lemak tanpa ester stanol) tidak berbeda bermakna terhadap kadar kolesterol total.
\end{abstract}

Kata kunci : ester stanol; kolesterol total; hiperkolesterolemia

\section{PENDAHULUAN}

Hiperkolesterolemia diketahui mempunyai hubungan kuat dengan keparahan aterosklerosis atau timbulnya lemak disaluran pembuluh darah yang dapat menyebabkan penyakit jantung dan pembuluh darah. ${ }^{1}$ Prevalensi penyakit jantung di Indonesia menurut RISKESDAS 2007 adalah $7,2 \%{ }^{2}$ Sedangkan rekapitulasi data kesakitan dinas kesehatan kota Semarang pada tahun 2012 menunjukkan jumlah kesakitan akibat penyakit jantung dan pembuluh darah adalah sebesar 13.847 dengan rentang umur 15-64 tahun. ${ }^{3}$

Pengaturan makan sehat dapat menurunkan kadar kolesterol total yang tinggi. ${ }^{4}$ American Heart Association (AHA) menganjurkan bahwa untuk mencapai profil lipid yang baik yaitu mengganti makanan yang mengandung lemak jenuh dengan makanan rendah lemak. Makanan rendah lemak sering dihubungkan pada produk susu rendah lemak yang difortifikasi dengan ester stanol yang berasal dari tumbuhan. ${ }^{5.6}$ Produk susu 
dengan tambahan ester stanol dikenal sebagai salah satu makanan fungsional yang digunakan untuk menurunkan kolesterol total. ${ }^{4}$

Ester stanol merupakan bentuk esterifikasi dari stanol, dimana stanol dalam bentuk bebas tidak dapat terdispersi di dalam air maupun lemak. ${ }^{7}$ Stanol adalah hasil hidrogenasi sterol, sterol didapatkan dari distilasi minyak sayur atau minyak pinus. Stanol ditambah dengan ester asam lemak dari minyak nabati atau minyak pinus menjadi ester stanol. ${ }^{8}$ Ester stanol memiliki struktur kimia yang hampir menyerupai kolesterol dan dapat menurunkan kolesterol dengan cara berkompetisi dengan kolesterol untuk membentuk misel pada saat proses absorpsi, sehingga terjadi penurunan absorpsi kolesterol di dalam usus halus. ${ }^{6,8}$ Ester stanol juga dapat mengaktifkan transporter protein yaitu Adenosine triphosphate Binding Cassette (ABC) pada dinding usus, sehingga kolesterol yang terserap di usus dapat dikeluarkan melalui feses. ${ }^{7}$ Produk ester stanol di pasaran Indonesia adalah ester stanol yang ditambahkan ke dalam susu rendah lemak yang dikemas dalam bentuk botol per $100 \mathrm{ml}$. Kandungan ester stanol dalam $100 \mathrm{ml}$ sebanyak $1,7 \mathrm{gg}^{10}$ Dosis optimal yang dianjurkan oleh Food Drug Association (FDA) untuk konsumsi stanol ester dalam menurunkan kadar kolesterol darah adalah 3,4-5,2 g. 7,10

Penelitian yang dilakukan di Finlandia oleh Maarit Hallikainen,et.al tahun 2002 kepada 11 subjek hiperkolesterolemia menunjukkan bahwa pemberian margarin dengan kandungan ester stanol $2 \mathrm{~g}$ per hari selama 2 minggu dapat menurunan kolesterol total secara signifikan yaitu 4.3 $\pm 8.1 .{ }^{11}$ Penelitian yang dilakukan di Korea oleh Yae Jung Hyu,et.al tahun 2005 kepada 23 subjek hiperkolesterolemia menunjukkan pemberian yoghurt dengan kandungan ester stanol 3,3 g per hariselama 2 minggu menunjukkan penurunan total kolesterol sebanyak $6 \% .^{12}$

Penelitian mengenai pengaruh pemberian ester stanol dalam yoghurt atau margarin telah dilakukan pada manusia, namun penelitian mengenai pengaruh pemberian ester stanol dalam susu rendah lemak pada manusia belum dilakukan. Hal ini yang mendasari dilakukannya penelitian ini, dengan mengambil subyek wanita usia subur.

\section{METODE}

Penelitian ini merupakan penelitian true experimental dengan rancangan pre-post test control design. Variabel bebas dalam penelitian ini adalah pemberian ester stanol 3,4 g dalam susu rendah lemak, sementara variabel terikat adalah kadar kolesterol total penderita

hiperkolesterolemia.

Ethical Clearance adalah bentuk persetujuan bahwa secara etik penelitian ini dapat dilakukan pada manusia. Oleh karena penelitian ini bersifat eksperimental yaitu memberikan intervensi khusus pada kelompok perlakuan dan kontrol, oleh karena itu penelitian ini dilaksanakan setelah mendapat persetujuan dari Komite Etik, Fakultas Kedokteran Universitas Diponegoro. Pengambilan data sampel termasuk pemeriksaan darah dilakukan setelah mendapat persetujuan dari subjek dengan mengisi informed consent.

Subyek penelitian merupakan guru dan karyawati SMA Negeri 1, SMA Negeri 3, dan SMA Negeri 5 Semarang. Kriteria inklusi penelitian ini adalah memiliki kadar kolesterol total $\geq 200 \mathrm{mg} / \mathrm{dl}$, belum mengalami menopause, tidak sedang mengonsumsi obat antihiperlipidemia selama penelitian, tidak dalam keadaan sakit atau dalam perawatan dokter berkaitan dengan penyakit jantung koroner, diabetes melitus, hipertensi, gagal ginjal, dan penyakit kronik lainnya, tidak sedang hamil atau menyusui, dan bersedia menjadi subyek penelitian dengan mengisi informed consent.

Perhitungan subjek penelitian menggunakan rumus uji hipotesis terhadap rerata dua populasi independen dan dibutuhkan sebanyak 28 subjek. Penentuan subjek penelitian menggunakan metode consecutive sampling. Sebanyak 57 orang bersedia diambil darahnya untuk proses skrining awal dan diperoleh sebanyak 28 orang yang memenuhi kriteria inklusi untuk menjadi subjek penelitian. Subjek dibagi menjadi 2 kelompok dengan metode simple randomization, yang terdiri atas kelompok kontrol dan kelompok perlakuan, masing-masing kelompok terdiri dari 14 subjek dengan cara dipilih acak berdasarkan undian nama. Kelompok perlakuan mendapatkan ester stanol sebanyak 3,4 gram/hari dalam susu rendah lemak $200 \mathrm{ml}$ dan kelompok kontrol mendapatkan plasebo berupa susu rendah lemak $200 \mathrm{ml}$ tanpa ester stanol.

Kelompok perlakuan menggunakan formula yang diformulasikan secara khusus dengan ester stanol dalam kemasan per $100 \mathrm{ml}$ susu skim yang mempunyai kandungan ester stanol $1.7 \mathrm{~g}$, energi total $50 \mathrm{kkal}$, energi dari lemak $20 \mathrm{kkal}$, lemak $2 \mathrm{~g}$, karbohidrat $7 \mathrm{~g}$, protein $1 \mathrm{~g}$, gula $7 \mathrm{~g}$ dan natrium $15 \mathrm{mg} .{ }^{10}$ Penelitian ini menggunakan ester stanol $3.4 \mathrm{~g}$ dalam $200 \mathrm{ml}$ susu skim per hari yang dikemas dalam botol.

Pemberian ester stanol dan plasebo dilakukan selama 14 hari. Asupan makan sehari- 
hari, pada kelompok kontrol dan kelompok perlakuan dikontrol menggunakan leaflet pengaturan makan sampel dengan diit 1900 kkal. Pencatatan makan dilakukan sebelum dan selama intervensi. Kepatuhan subjek mengonsumsi ester stanol dan plasebo dicatat dengan menggunakan formulir kepatuhan.

Kadar kolesterol total dianalisis dengan pemeriksaan laboratorium menggunakan metode Cholesterol Oxidase Para Aminophenazone (CHOD-PAP). Sampel darah diambil oleh petugas laboratorium setelah subjek berpuasa selama \pm 10 jam. Data asupan makan subjek dianalisis menggunakan program nutrisurvey.

Karakteristik subyek dianalisis menggunakan analisis deskriptif. Uji normalitas menggunakan uji Shapiro-Wilk. Uji dependent t- test digunakan untuk menganalisis kadar kolesterol total sebelum dan sesudah intervensi, asupan energi, protein, karbohidrat, kolesterol, dan serat. Non parametrik Wilcoxon digunakan untuk menganalisis asupan lemak. Uji independent t-test digunakan untuk melihat kadar kolesterol total sebelum intervensi. Data yang tidak normal diuji dengan uji Mann-Whitney yaitu untuk melihat IMT.

\section{HASIL PENELITIAN \\ Karakteristik Subjek}

Karakteristik subyek yang terdiri dari gambaran umur, status gizi, aktivitas fisik, dan kadar kolesterol total awal subyek sebelum penelitian disajikan dalam tabel 1 .

Tabel 1. Karakteristik subjek

\begin{tabular}{|c|c|c|c|c|c|c|c|}
\hline \multirow[t]{2}{*}{ Variabel } & \multicolumn{4}{|c|}{$\begin{array}{c}\text { Perlakuan } \\
(n=14)\end{array}$} & \multicolumn{2}{|c|}{$\begin{array}{c}\text { Kontrol } \\
(n=14)\end{array}$} & \multirow[t]{2}{*}{$\mathbf{P}$} \\
\hline & Mean \pm SD & $\mathbf{N}$ & $\%$ & Mean \pm SD & $\mathbf{N}$ & $\%$ & \\
\hline Umur & & & & & & & 0.451 \\
\hline 27-37 & & 3 & $10.7 \%$ & & 2 & $7.1 \%$ & $*$ \\
\hline $38-47$ & $44.15 \pm 8.146$ & 5 & $17.9 \%$ & $45.84 \pm 8.48$ & 4 & $14.3 \%$ & \\
\hline 48-57 & & 6 & $21.4 \%$ & & 8 & $28.6 \%$ & \\
\hline Status Gizi & & & & & & & 0.655 \\
\hline Normal $\left(18,5-22,9 \mathrm{~kg} / \mathrm{m}^{2}\right)$ & & 3 & $10.7 \%$ & & 2 & $7.1 \%$ & $*$ \\
\hline $\begin{array}{l}\text { Overweight }(23-24,9 \\
\left.\mathrm{kg} / \mathrm{m}^{2}\right)\end{array}$ & $25.81 \pm 3.84$ & 3 & $10.7 \%$ & $27.03 \pm 3.99$ & 3 & $10.7 \%$ & \\
\hline Obesitas $\left(>25 \mathrm{~kg} / \mathrm{m}^{2}\right)$ & & 8 & $28.6 \%$ & & 9 & $32.1 \%$ & \\
\hline Aktivitas Fisik & & & & & & & \\
\hline Ringan & $1.85 \pm 0.36$ & 2 & $7.1 \%$ & $1.78 \pm 0.42$ & 3 & $10.7 \%$ & 0.628 \\
\hline Sedang & & 12 & $42.9 \%$ & & 11 & $39.3 \%$ & $*$ \\
\hline Kolesterol total awal & $\begin{array}{c}236.78 \pm 22.0 \\
1\end{array}$ & 14 & $100 \%$ & $\begin{array}{l}239.50 \pm 34.3 \\
5\end{array}$ & 14 & $100 \%$ & $\begin{array}{c}0.80^{*} \\
*\end{array}$ \\
\hline
\end{tabular}

*Mann Whitney**Uji beda independent t-test

Sebagian besar subjek dalam penelitian ini berada pada kelompok umur 48-57 tahun (50\%), sebagian besar memiliki kategori status gizi obesitas $(60.7 \%)$. Rerata kadar kolesterol total awal baik kelompok perlakuan maupun kontrol diatas $200 \mathrm{mg} / \mathrm{dl}$. Hasil uji beda menunjukkan tidak terdapat perbedaan umur, status gizi, aktivitas fisik dan kolesterol total awal antara kelompok perlakuan dengan kelompok kontrol ( $\mathrm{p}>0.05)$.

Perbedaan dan perubahan asupan makan sebelum dan selama intervensi

Perbedaan dan perubahan asupan makan subyek sebelum dan selama intervensi antara kedua kelompok disajikan dalam tabel 2 .

Tabel 2. Perbedaan dan perubahan asupan sebelum dan sesudah intervensi

\begin{tabular}{lll}
\hline Asupan & $\begin{array}{l}\text { Perlakuan } \\
(\mathbf{n}=\mathbf{1 8}) \\
\text { Mean } \pm \text { SD }\end{array}$ & $\begin{array}{l}\text { Kontrol } \\
(\mathbf{n}=\mathbf{1 8}) \\
\text { Mean } \pm \text { SD }\end{array}$ \\
\hline Energi pre & $1964.83 \pm 125.6$ & $1920.88 \pm 108.2$ \\
Energi & 6 & 1 \\
\hline
\end{tabular}




\begin{tabular}{llll}
\hline intervensi & $1930.81 \pm 120.6$ & $1907.20 \pm 124.5$ & $0.711^{3}$ \\
$\Delta$ energi & 5 & 5 & \\
$\mathbf{P}$ & $34.02 \pm 132.31$ & $13.68 \pm 154.10$ & \\
& $-0.354^{1}$ & $0.470^{2}$ & \\
\hline Protein pre & $72.18 \pm 14.88$ & $68.29 \pm 3.74$ & $1.00^{3}$ \\
Protein & $69.19 \pm 11.11$ & $65.30 \pm 8.3$ & \\
intervensi & $2.99 \pm 12.74$ & $2.99 \pm 7.66$ & \\
$\Delta$ protein & $0.396^{1}$ & $0.168^{1}$ & $0.520^{4}$ \\
p & & & \\
\hline KH pre & $241.87 \pm 13.97$ & $247.84 \pm 25.99$ & \\
KH intervensi & $245.40 \pm 21.21$ & $254.79 \pm 20.68$ & $0.449^{3}$ \\
$\Delta$ karbohidrat & $-3.53 \pm 23.84$ & $-6.95 \pm 22.93$ & \\
p & $0.588^{1}$ & $0.277^{1}$ & \\
\hline Lemak pre & $63.72 \pm 14.10$ & $63.75 \pm 4.06$ & \\
Lemak & $67.96 \pm 5.40$ & $64.70 \pm 3.00$ & \\
intervensi & $-4.24 \pm 15.27$ & $-0.95 \pm 4.81$ & \\
$\Delta$ lemak & $0.158^{2}$ & $0.473^{1}$ & \\
p & & & \\
\hline Kolesterol pre & $270.60 \pm 77.80$ & $259.26 \pm 77.57$ & \\
Kolesterol interv & $238.46 \pm 51.37$ & $217.20 \pm 64.92$ & \\
$\Delta$ kolesterol & $32.14 \pm 60.90$ & $42.05 \pm 102.44$ & \\
p & $0.070^{1}$ & $0.149^{1}$ & \\
\hline Serat pre & $15.49 \pm 3.02$ & $15.55 \pm 4.265$ & \\
Serat intervensi & $12.70 \pm 3.07$ & $14.47 \pm 2.82$ & \\
$\Delta$ serat & $2.78 \pm 4.89$ & $0.470^{3}$ & \\
p & $0.053^{1}$ & & \\
\hline
\end{tabular}

${ }^{1}$ uji paired sample t- test, ${ }^{2}$ uji Wilcoxon, ${ }^{3}$ uji independent t- test, ${ }^{4}$ uji Mann-Whitney,

Berdasarkan tabel 2, diketahui bahwa tidak terdapat perbedaan asupan energi, protein, karbohidrat, lemak, kolesterol, dan serat sebelum dan sesudah intervensi antara kedua kelompok $(\mathrm{p}>0.05)$. Tidak terdapat perubahan asupan antara

Pengaruh konsumsi ester stanol terhadap kadar kolesterol total

Pengaruh konsumsi ester stanol terhadap kadar kolesterol total disajikan dalam tabel 3. kedua kelompok $(\mathrm{p}>0.05)$.

Tabel 3. Pengaruh konsumsi ester stanol terhadap kadar kolesterol total

\begin{tabular}{cccccccc}
\hline Kelompok & $\mathrm{N}$ & $\begin{array}{c}\text { Kolesterol } \\
\text { Total Awal } \\
(\mathrm{mg} / \mathrm{dl})\end{array}$ & $\begin{array}{c}\text { Kolesterol } \\
\text { Total Akhir } \\
(\mathrm{mg} / \mathrm{dl})\end{array}$ & $\mathrm{p}^{*}$ & $\begin{array}{c}\Delta \text { Kol. Total } \\
(\mathrm{mg} / \mathrm{dl})\end{array}$ & $\Delta \%$ & $\mathrm{p}^{* *}$ \\
\hline Perlakuan & 14 & $236.78 \pm 22.01$ & $216.14 \pm 30.78$ & 0.005 & $20.64 \pm 22.96$ & $8.71 \%$ & 0.448 \\
Kontrol & 14 & $239.50 \pm 34.35$ & $222.57 \pm 26.05$ & 0.042 & $16.92 \pm 28.11$ & $7.06 \%$ & \\
\hline
\end{tabular}

*uji beda paired sample $\mathrm{t}$ test **uji Mann Whitney

Hasil uji beda pada tabel 6 menunjukkan adanya perbedaan kadar kolesterol total sebelum dan setelah intervensi pada kelompok perlakuan maupun kontrol $(\mathrm{p}<0.05)$. Penurunan kolesterol total pada kelompok perlakuan $8.71 \%$, sedangkan pada kelompok kontrol $7.06 \%$. Tidak terdapat perbedaan perubahan kadar kolesterol total bermakna antara kelompok perlakuan dengan kelompok kontrol $(\mathrm{p}>0.05)$.

\section{PEMBAHASAN}

Karakteristik subyek dalam penelitian ini adalah wanita hiperkolesterolemia dan belum mengalami menopause. Sebagian besar subyek berada pada kelompok umur 48-57 tahun (14 orang), sementara status gizi subyek sebagian besar adalah obesitas (17 orang). Namun secara keseluruhan, tidak terdapat perbedaan karakteristik 
subyek pada awal penelitian, sehingga dapat disimpulkan subyek tergolong homogen.

Wanita usia subur masih memiliki hormon estrogen yang berfungsi sebagai kardioprotektif atau mencegah terbentuknya plak di pembuluh darah arteri. Namun, dalam keadaan pre menopause atau menopause, hormon estrogen pada wanita akan berkurang dan dapat meningkatkan risiko terjadinya penyakit jantung dan pembuluh darah. ${ }^{14}$

Status gizi dalam penelitian ini sebagian besar adalah obesitas (17 orang). Hasil penelitian di Finlandia pada laki-laki dan perempuan berusia 30-49 tahun menunjukkan bahwa kadar kolesterol dalam serum berhubungan secara positif dengan IMT. Subyek overweight dan obesitas memiliki risiko terjadinya PJK 1,79 kali lebih besar dibandingkan kelompok underweight dan ideal karena pada penderita obesitas terdapat gangguan metabolisme lipoprotein. ${ }^{4,15}$ Obesitas dapat menyebabkan gangguan regulasi asam lemak yang akan meningkatkan kadar trigliserida dan ester kolesterol. Peningkatan trigliserida yang besar dalam sirkulasi akan meningkatkan kolesterol yang terdapat pada VLDL dan LDL sekunder karena terjadi penumpukan lemak berlebihan didalam tubuh dan meningkatkan kadar kolesterol total. ${ }^{16,17}$

Subyek penelitian sebagian besar bekerja sebagai guru SMA yang aktif mengajar, sisanya sebagian kecil adalah pegawai administrasi di sekolah. Sebagian besar subyek memiliki aktivitas fisik sedang (82.2\%). Aktivitas fisik dan olah raga yang kurang dapat menghambat aliran darah dan meningkatkan terjadinya penyakit kardiovaskular, dengan faktor risiko yaitu obesitas, lipid darah, glukosa darah, dan hipertensi. ${ }^{17}$ Meningkatkan aktivitas fisik berkaitan dengan penurunan berat badan. Cara tersebut efektif untuk menurunkan kolesterol LDL dan VLDL serta meningkatkan kadar kolesterol HDL. ${ }^{18}$

Asupan makan subyek sebelum dan selama intervensi antara dua kelompok tidak menunjukkan perbedaan bermakna. Rerata asupan energi seluruh subyek sebelum dan selama dilakukan intervensi yaitu 1930.93 kkal yang berarti telah memenuhi kecukupan yang dianjurkan melalui leaflet pengaturan makan $1900 \mathrm{kkal}$.

Rerata asupan serat kelompok perlakuan saat diberikan intervensi $(12.70 \mathrm{~g})$ mengalami penurunan dibandingkan dengan sebelum intervensi (15.49 g). Pada kelompok kontrol, rerata asupan serat mengalami penurunan dalam jumlah kecil, yaitu $15.55 \mathrm{~g}$ menjadi $14.47 \mathrm{~g}$. Rerata asupan serat seluruh subjek penelitian yaitu $13.58 \mathrm{~g}$.
Namun, secara statistik tidak ada perbedaan bermakna sebelum dan selama intervensi baik kelompok perlakuan maupun kelompok kontrol. Anjuran kecukupan serat harian yang direkomendasikan oleh American Dietetic Association (ADA) yaitu 20-35 g/hari atau berdasarkan Dietary Reference Intake (DRI) setara dengan $14 \mathrm{~g} / 1000$ kkal. $^{19}$ Subyek secara keseluruhan belum mencukupi kebutuhan serat yang dianjurkan per hari.

Pemberian ester stanol sebanyak 3,4 gram/hari selama 14 hari pada kelompok perlakuan dapat menurunkan kadar kolesterol total lebih banyak dibandingkan dengan kelompok kontrol. Hasil penelitian menunjukkan bahwa kadar kolesterol total sebelum intervensi pada kelompok perlakuan adalah $236.78 \mathrm{mg} / \mathrm{dl}$ dan pada kelompok kontrol $239.5 \mathrm{mg} / \mathrm{dl}$. Hasil uji statistik menunjukkan adanya perbedaan kadar kolesterol total sebelum dan setelah intervensi pada kelompok perlakuan maupun kontrol $(\mathrm{p}<0.05)$. Penurunan kolesterol total terjadi secara signifikan pada kelompok perlakuan sebesar $8.71 \%$. Hal ini sejalan dengan penelitian yang dilakukan di Finlandia oleh Maarit Hallikainen,et.al tahun 2002 kepada 11 subjek hiperkolesterolemia menunjukkan bahwa pemberian margarin dengan kandungan ester stanol $2 \mathrm{~g}$ per hari selama 2 minggu dapat menurunan kolesterol total secara signifikan yaitu $-4.3 \pm 8.1 \% .{ }^{11}$ Rata-rata peningkatan asupan kolesterol $100 \mathrm{mg} /$ hari dapat meningkatkan serum kolesterol 2-3 mg/dl. ${ }^{5}$

Ester stanol merupakan bentuk esterifikasi dari stanol, dimana stanol dalam bentuk bebas tidak dapat terdispersi di dalam air maupun lemak. ${ }^{7}$ Stanol terbentuk melalui proses hidrogenasi murni dari sterol, sterol didapatkan dari distilasi minyak sayur atau minyak pinus. Produksi sterol dari pinus diawali dengan Kraft Pulping Process untuk menghasilkan serat kayu. Proses ini dilakukan selama 18 jam pada suhu $50^{\circ} \mathrm{C}$ dalam kondisi basa $(\mathrm{pH}=14)$, lalu dilanjutkan dengan soapy lipid phase untuk memperoleh sterol lebih dari 2\%. Sterol dilarutkan dengan methanol kemudian diekstraksi, dimurnikan dan diasamkan agar dapat memproduksi oily phase. Oily phase mengandung free rosin, asam lemak, dan komponen netral yang meliputi sterol, alkohol, skualen, wax dan ester. Kandungan-kandungan ini disebut crude tall oil. Crude tall oil dimurnikan dengan proses distilasi dimana sterol terkonsentrasi dan ester sterol sebagai sisanya. Sterol murni terbentuk dari tall oil pitch. $^{10}$ 
Sterol minyak pohon pinus mengandung 90\% sitostanol dan 10\% campestanol. Kadar stanol yang didapatkan dari sterol minyak pohon pinus dapat mencapai $15 \% .{ }^{10}$ Stanol ditambah dengan ester asam lemak dari minyak nabati atau minyak pinus agar menjadi ester stanol. ${ }^{7}$ Dosis optimal yang dianjurkan oleh Food Drug Association (FDA) untuk konsumsi stanol ester dalam menurunkan kadar kolesterol darah adalah 3,4-5,2 g. ${ }^{6}$ Konsumsi berlebihan dapat memiliki efek samping dapat menurunkan sedikit konsentrasi karotenoid hidrokarbon (a-karoten, b-karoten, dan likopen), tokoferol dan karotenoid yang mengalami oksidasi seperti lutein, zeaxanthin, criptoxanthin. ${ }^{9,18,20}$ Penurunan tersebut disebabkan oleh menurunnya LDL yang bertugas untuk membawa antioksidan tersebut. ${ }^{21}$ Ester stanol terdapat pada kacang, minyak sayur, sereal, gandum. Ester stanol dikenal dapat menurunkan kolesterol, oleh karena itu ester stanol sering digabungkan dengan berbagai macam produk makanan dan biasa disebut makanan fungsional. ${ }^{9}$

Stanol dan bentuk esternya merupakan komponen yang stabil pada suhu tinggi, ester stanol tahan terhadap oksidasi dan hanya terdegradasi sedikit pada saat pemrosesan minyak. ${ }^{7}$ Contoh fortifikasi ester stanol yang pernah dilakukan adalah susu rendah lemak, yoghurt rendah lemak, roti, jus jeruk, coklat bar dan sereal. Di Indonesia, produk yang mengandung ester stanol hanya ada satu yaitu susu asam atau susu rendah lemak. ${ }^{10}$

Ester stanol memiliki struktur kimia yang hampir menyerupai kolesterol dan dapat menurunkan kolesterol dengan cara berkompetisi dengan kolesterol untuk membentuk misel pada saat proses absorpsi, sehingga terjadi penurunan absorpsi kolesterol di dalam usus halus. ${ }^{6,7,9}$ Ester stanol juga dapat mengaktifkan transporter protein yaitu Adenosine triphosphate Binding Cassette (ABC) pada dinding usus, sehingga kolesterol yang terserap di usus dapat dikeluarkan melalui feses. ${ }^{7}$ Kolesterol yang terserap oleh usus akan berkurang karena berkompetisi dengan ester stanol, sehingga akan terjadi rangsangan timbal balik negatif (negative feedback mechanism) pada regulasi $\mathrm{HMG} \mathrm{CoA}$ reduktase untuk mensistesis kolesterol dari asetil-KoA di dalam hepar. ${ }^{5}$ Kolesterol yang disintesis oleh hepar disekresikan dan akan terikat dengan VLDL. Di dalam sirkulasi, VLDL akan berubah menjadi IDL dengan berkurangnya trigliserid yang dibawa dan yang terakhir yaitu menjadi LDL yang kaya akan kolesterol. $^{22,23}$
Pemberian ester stanol yang diformulasikan ke dalam susu rendah lemak secara statistik tidak ada perbedaan penurunan kadar kolesterol total antara kelompok perlakuan $(8.71 \%)$ dan kelompok kontrol (7.06\%). Susu merupakan bahan makanan yang kompleks karena memiliki kandungan gizi bermacam-macam. Asam lemak susu, kalsium, protein dan peptida diketahui dapat menurunkan kadar kolesterol total. Penelitian yang dilakukan di Amerika tahun 2013 mengenai pengaruh pemberian susu selama 6 bulan pada 16 subyek pemberian susu rendah lemak, dapat diketahui susu rendah lemak dapat menurunkan kadar kolesterol total, namun secara statistik tidak bermakna $(1.1 \pm 3.1){ }^{24}$ Kemungkinan selanjutnya, penurunan kadar kolesterol total pada kelompok kontrol disebabkan oleh pengaturan makan melalui leaflet yang mempengaruhi subyek mengurangi makanan yang mengandung tinggi kolesterol dibuktikan dengan hasil recall asupan kolesterol sebelum intervensi memiliki rata-rata $259.26 \mathrm{mg}$ dan selama intervensi menjadi 217.20.

Upaya menurunkan kadar kolesterol total, selain mengkonsumsi ester stanol juga perlu didukung dengan perubahan pola hidup diantaranya dengan cara mengurangi asupan kolesterol dan meningkatkan asupan serat. Rerata asupan kolesterol kelompok kontrol sebelum intervensi yaitu $259.26 \mathrm{mg}$ dan setelah intervensi turun menjadi $217.2 \mathrm{mg}$, sedangkan pada kelompok perlakuan sebelum intervensi $270.60 \mathrm{mg}$ dan setelah intervensi juga turun menjadi 238.46 $\mathrm{mg}$, hal ini menunjukkan bahwa asupan kolesterol subjek mendekati anjuran (>200 mg).

\section{KESIMPULAN}

Pemberian ester stanol $3.4 \mathrm{~g}$ per hari selama 14 hari terhadap kadar kolesterol total dibandingkan dengan kelompok kontrol (susu rendah lemak tanpa ester stanol) tidak berbeda bermakna. Pemberian ester stanol terhadap kadar kolesterol total mengalami penurunan lebih besar $(8.71 \%)$ dibandingkan dengan kelompok kontrol $(7.06 \%)$.

\section{SARAN}

1. Ester stanol yang ditambahkan ke dalam makanan sesuai anjuran FDA dapat digunakan sebagai alternatif untuk membantu menurunkan kadar kolesterol total pada penderita hiperkolesterolemia.

2. Produk susu dengan tambahan ester stanol yang dipasarkan sebaiknya disesuaikan dengan anjuran konsumsi (3.4-5.2 g/200 ml), sehingga 
penurunan profil lipid yang diharapkan dapat tercapai.

3. Ester stanol tidak hanya terdapat pada kayu pinus, namun juga terdapat pada minyak sayur atau gandum. Perlu dilakukan penelitian lebih lanjut mengenai efek penurunan kadar kolesterol total dan trigliserida pada minyak sayur atau gandum.

\section{UCAPAN TERIMAKASIH}

Rasa terima kasih penulis ucapkan kepada Tuhan Yang Maha Esa, orang tua yang telah membiayai penelitian ini, seluruh responden yang telah ikut berpartisipasi dalam penelitian ini, pembimbing dan para penguji atas bimbingan dan masukan yang membangun, serta berbagai pihak yang telah memberi dukungan dan motivasi dalam penyusunan karya tulis ilmiah ini.

\section{DAFTAR PUSTAKA}

1. Carolt TB. Penyakit Aterosklerotik koroner. In : Sylvia A. Price, Lorraine M. Wilson. Patofisiologi Konsep Klinis Proses-Proses Penyakit. Edisi 6. Jakarta: Penerbit buku kedokteran EGC; 2006.p.576-612

2. Keputusan Menteri Kesehatan Republik Indonesia Nomor 854/Menkes/SK/IX/2009 tentang pedoman pengendalian penyakit jantung dan pembuluh darah.

3. Laporan Dinas Kesehatan Kota Semarang. Rekapitulasi Data Kesakitan Tahun 2012

4. Fletcher Barbara, Berra Kathy, Ades Phil, T Lynne, editors. Managing Abnormal Blood Lipids: A Collaborative Approach. American Heart Association Journals. 2005; 112: 3184-3209

5. Suhad S AbuMweis, Roula Barake, Peter J.H. Jones. Plant sterols/stanols as cholesterol lowering agents: A meta-analysis of randomized controlled trials. Food \& Nutrition Research. Coaction Publishing. 2008; 10: 3420-1811

6. Simone RBM Eussen. Cathy JM Rompelberg, Olaf $\mathrm{H}$ Klungel, Jan $\mathrm{CH}$ van Eijkeren. Modelling approach to simulate reductions in LDL cholesterol levels after combined intake of statins and phytosterols/-stanols in humans. Lipids in Health and Disease. 2011. 10:187

7. Kamal-Eldin, Afaf, Moazzami, Ali. Plant Sterols and Stanols as Cholesterol-Lowering Ingredients in Functional Foods. Recent Patents on Food, Nutrition \& Agriculture Pubmed. 2008; 1: 1-14

8. Acuff, Robert V, Cai, D J, Dong, Zhi-Ping, Bell, Doris. The lipid lowering effect of plant sterol ester capsules in hypercholesterolemic subjects. BioMed Central. 2007; 6-11

9. Arie"nne de Jong, Jogchum Plat, Ronald P. Metabolic effects of plant sterols and stanols
(Review). Journal of Nutritional Biochemistry. 2003; 14.p.362-69

10. Cantrill, Richard. Phytosterols, phytostanol and their esters. Chemical and Technical Assesment. 2008; p.1-13

11. Hallikainen Maarit, Sarkkinen Essi, Wester Ingmar, Uusitupa Matti. Short-term LDL cholesterol-lowering efficacy of plant stanol esters. BioMed Central. 2002; 2:14

12. Hyun, Jung Yae, Kim, Yoen Oh, Kang, Joo Byung, Lee, Jong Ho, Jang Yangsoo, Liponkoski, Lippo, Salo, Pia. Plant stanol esters in low-fat yogurt reduces total and low-density lipoprotein cholesterol and low-density lipoprotein oxidation in normocholesterolemic and mildly hypercholesterolemic subjects. Nutrition Research Elsevier. 2005; 25.p.743-753.

13. PT Ultra Jaya Milk Industry Tbk.

http://www.ultrajaya.co.id/uhtfreshmilk/ultramilklowfa thighcalcium/?ver=ind

14. Trapani, Laura, Valentina, Pallottini. Age-Related Hypercholesterolemia and HMG-CoA Reductase Dysregulation: Sex Does Matter (A Gender Perspective). Hindawi Publishing Corporation. 2010; vol.2010 (7) 10:1155

15. Mawi, Martiem. Indeks massa tubuh sebagai determinan penyakit jantung koroner pada orang dewasa berusia diatas 35 tahun. Jurnal Kedokteran Trisakti. 2004. Vol 23 no. 3

16. Mayes PA. Sintesis, Pengangkutan, dan Ekskresi Kolesterol. Dalam: Murray RK, Granner DK, Mayes PA, Rodwell VW, editor. Biokimia harper $24^{\text {th }}$ ed. Jakarta: EGC; 1999.p.277;89

17. Feldman EB, Cooper GR. Assessment of Lipids and Lipoproteins. In : Berdanier CD, Feldman EB, Dwyer J, editor. Handbook of Nutrition and Food. Second edition. New York, Taylor \& Francis Group; 2008.p.683;9

18. Krummel DA. Medical nutrition therapy for cardiovascular disease. In: Mahan LK, Escottstump S, editors. Krause's food, Nutrition and Diet Therapy. $12^{\text {th }}$ ed. USA: Saunders;2008.p.839.

19. Nishida C, Uauy R, Kumanyika S, Shetty P. The joint $\mathrm{WHO} / \mathrm{FAO}$ expert consultation on diet, nutrition and the prevention of chronic diseases: process, product and policy implications. Public Health Nutrition. 2004. 7(1A), p245;50

20. Gylling, Helena, Hallikainen, Maarit, Nissinen, Markku J, A Miettinen, Tatu. The effect of a very high daily plant stanol ester intake on serum lipids, carotenoids, and fat-soluble vitamins. Clinical Nutrition Elsevier Journal. 2010;29.p.112-118.

21. Ronald P Mensink, Arienne de Jong, Dieter Lütjohann, Guido RMM Haenen, Jogchum Plat. Plant stanol dose-dependently LDL-cholesterol concentrations, but not cholesterol-standardized fat-soluble antioxidant concentrations, at intakes up to $9 \mathrm{~g} / \mathrm{d}$. The American Journal of Clinical Nutrition. 2010;92.p.24-33. 
22. He, Jiang, Dongfeng Gu, Kristi Reynolds, Xigui Wu, Paul Muntner, Jiangong Zhao, Jing Chen Donghai Liu, Jingping Mo, Paul K. Whelton. Serum Total and Lipoprotein Cholesterol Levels and Awareness, Treatment, and Control. Journal of the American Heart Association. 2004; 110:405411

23. Stacy. LM, Robert JR, Karen CN. Prevalence of CVD risk factors and impact of a two year education program for premenopausal woman. Elsevier Science (Pubmed). 2001; 11. No.6.

24. Rideout, Todd C, Marinangeli, Christopher P F, Martin, Heather, Browne, Richard W, Rempel Curtis B. Consumption of low-fat dairy foods for 6 months improves insulin resistance without adversely affecting lipids or bodyweight in healthy adults: a randomized free-living cross-over study. Nutrition Journal BioMed Central. 2013; 12:56 